\title{
Effect of Bud Load and Rootstock Cultivar on the Performance of $V$. vinifera L. cv. Red Muscadel (Muscat noir)
}

\author{
E. Archer* and G.W. Fouché \\ 7600 Stellenbosch, Republic of South Africa. \\ Submitted for publication: October 1986 \\ Accepted for publication: January 1987 \\ Keywords: Bud load, rootstock cultivars, crop load, Vitis vinifera.
}

Assistant-Director Viticulture and Senior Research Technician respectively, Viticultural and Oenological Research Institute, Private Bag X5026,

\begin{abstract}
The effect of four different bud loads and six rootstock cultivars on the performance of $V$. vinifera $\mathbf{L}$. cv. Red Muscadel (Muscat noir) was investigated. Parameters such as yield, cane, cluster and berry mass, budding percentage, bud fertility, leaf surface area, grape composition and wine quality were measured in an effort to establish the best rootstock and bud load for this cultivar. Both bud load and rootstock cultivar had significant effects on all parameters measured. The effect of bud loads depended on the rootstock cultivar used. Considering all parameters, the rootstock cultivars 110 Richter and Ramsey showed the best performance.
\end{abstract}

The quantitative and qualitative performance of grapevines is greatly affected by the crop load per vine as induced by pruning severity (Antcliff, 1965; Weaver \& Pool, 1968; Lider, Kasimatis \& Kliewer, 1973; Cawthon \& Morris, 1977; Balasubrahmanyam, Eifert \& Diofasi, 1978; 1979; Freeman, Lee \& Turkington, 1979; 1980; Morris \& Cawthon, 1980; Zeeman \& Archer, 1981; Archer, 1983; 1984; 1985). It is generally accepted that wine quality is adversely affected by overcropping since only a certain amount of grapes per vine can reach optimum maturity (Winkler, 1964). Weaver, Amerine \& Winkler (1957) reported that low crop loads resulted in wines with better colour expression, higher alcohol concentration and higher tannin content than wines made from higher crop loads. This is in accordance with results obtained by Weaver, McCune \& Amerine (1962); Winkler (1964); Weaver \& Pool (1968); Freeman et al. (1980). By using cluster thinning to obtain different crop loads Kliewer, Freeman \& Hossom (1983); Bravdo et al. (1984; 1985a; 1985b); Hepner et al. (1985) and Hepner \& Bravdo (1985) achieved similar results. All the above mentioned results, however, were obtained for high bud loads ranging from 40 to 160 buds per vine (6 to 15 buds per $\mathrm{m}^{2}$ soil surface). Jooste (1983) reported no decrease in wine quality with increasing bud load, ranging from three to six buds per $\mathrm{m}^{2}$ soil surface, for Chenin blanc under irrigation. From the above literature it was also evident that scion and rootstock cultivar, trellising system and locality exert an important effect on the results obtained with different bud loads.

Most authors reporting on the effect of bud load on wine quality identified delayed ripening as an important negative result of higher cropping levels (Weaver et al.,1962; Winkler, 1964; Lider, Kasimatis \& Kliewer, 1973, 1975; Cawton \& Morris, 1977; Balasubrahmanyam et al., 1979; Freeman et al., 1980; Christensen, 1981) and in most cases a degeneration of the bunches (smaller, loose berries) also occurred. Personal observations showed that in South Africa the effect of overcropping differs between cultivars as well as different clones of the same cultivar. It appears that cultivars with skin related quality factors (colour, aroma and taste), viz. Chardonnay, Weisser Riesling, Sauvignon blanc and Pinot noir, are more susceptible to a decrease in quality with high crop loads, than neutral cultivars such as Chenin blanc, Colombar, Palomino and Ugni blanc. It was also found that different clones of Weisser Riesling reacted differently to high crop loads.

The effect of bud load on the performance of vines, therefore, depends on the cultivar, clone, rootstock, trellising system and locality and a general recommendation concerning pruning severity cannot be made. This investigation deals with the effect of bud load on the performance of locally selected Vitis vinifera L. cv. Red Muscadel grafted onto different rootstocks in order to make a bud load recommendation for this important cultivar in the Breede River Valley.

\section{MATERIALS $f$ :ND METHODS}

\section{Experimental vineyard:}

The experiment was carried out on a six year old Vitis vinifera L. cv Red Muscadel (Muscat noir or Muscat de Frontignan) vineyard on the V.O.R.I., Robertson experimental farm in the Breede River Valley (climatic region IV). The cultivar was grafted onto six different rootstocks, namely 101-14 Mgt (V. riparia Michx. x $V$. rupestris Scheele); 99 Richter (V. Berlandieri Planch. var. Las Sorres x V. rupestris var. du Lot); 110 Richter $(V$. Berlandieri var. Rességuier No $2 \times V$. rupestris var. Martin); Ramsey (var. of $V$. Champini); Constantia Metallica (seedling of $V$. rupestris var. Martin) and $\mathrm{Ru}-$ pestris du Lot (V. rupestris var. du Lot). Vines were grown on a red, medium textured calcareous soil and trained onto a lengthened double Perold trellising system (Zeeman, 1981). The vines were spaced 3,0 $\mathrm{m} \mathrm{x}$ $1,5 \mathrm{~m}$ and spur pruned using two bud spurs. The bud load was controlled by desuckering once early during every season. Using A-pan evaporation data, approximately $80 \mathrm{~mm}$ water per month was sprinkler irrigated during the growing season.

\section{Experimental design:}

A randomized block design was used to accommodate six rootstocks and four bud load treatments (16, 24,32 and 40 buds per vine) were allocated per rootstock using a split plot design. Each treatment was rep- 
licated three times and five vines per plot were visually selected for uniformity and used for measurements.

\section{Data collection:}

Data were collected over a seven year period and included the following: crop, cane, cluster and berry mass, budding percentage (number of sprouted buds as percentage of total number of buds left during pruning), bud fertility (number of clusters per sprouted bud), total leaf surface area per vine, sugar $\left({ }^{\circ} \mathrm{B}\right)$ and acid concentrations (total titratable acidity expressed as tartaric acid $=$ TTA), $\mathrm{pH}$ and wine quality. The colour expression of the berries is reported by Hunter \& De la Harpe (1987). All plots were harvested on the same date.

\section{Statistical analyses:}

Statistical analyses were done using a BMDP statistical software package (Dixon et al., 1983).

\section{RESULTS AND DISCUSSION}

\section{Crop and cane mass:}

Both the rootstock and bud load had significant effects on the yield (Table 1). The highest crop mass was obtained with 110 Richter pruned to a bud load of 40 buds per vine, while Rupestris du Lot with 16 buds per vine had the lowest crop mass. It is evident that the crop mass obtained with a specific bud load depended largely on the rootstock cultivar used. In general, crop mass increased with bud load. In the case of Ramsey, Constantia Metallica and Rupestris du Lot, this tendency was not obtained after 32 buds per vine. The highest yield per bud load was obtained with 110 Richter as rootstock with the exception of Ramsey pruned to 32 buds per vine.

Although more irregular differences occurred with cane than with crop mass, it is clear that the rootstock cultivar had a marked effect on the growth vigour obtained with different bud loads (Table 1). The lowest cane mass was obtained with Rupestris du Lot pruned to 40 buds per vine, while the highest cane mass was found with Ramsey pruned to 16 buds per vine. There was a general tendency for higher bud loads to reduce vegetative growth and the cane mass was significantly lower at 40 buds than at 16 buds per vine. Ramsey induced the highest vegetative growth of all the rootstocks.
Zeeman \& Archer (1981) found that the optimum ratio of crop to cane mass for Chenin blanc was between seven and nine for this region. Fig. 1 shows that, except in the cases of Ramsey and 101-14 Mgt, this ratio was surpassed with a bud load of 40 buds per vine for all rootstock cultivars. In the case of 99 Richter this optimum ratio was surpassed with 32 buds per vine. For the last two seasons a ratio of 12 was surpassed with bud loads of 32 and 40 buds per vine on 99 Richter and Rupestris du Lot, showing that overcropping is taking place on these two rootstocks (data not shown). This indicates that the rootstock cultivar should be considered when decisions concerning bud load are made.

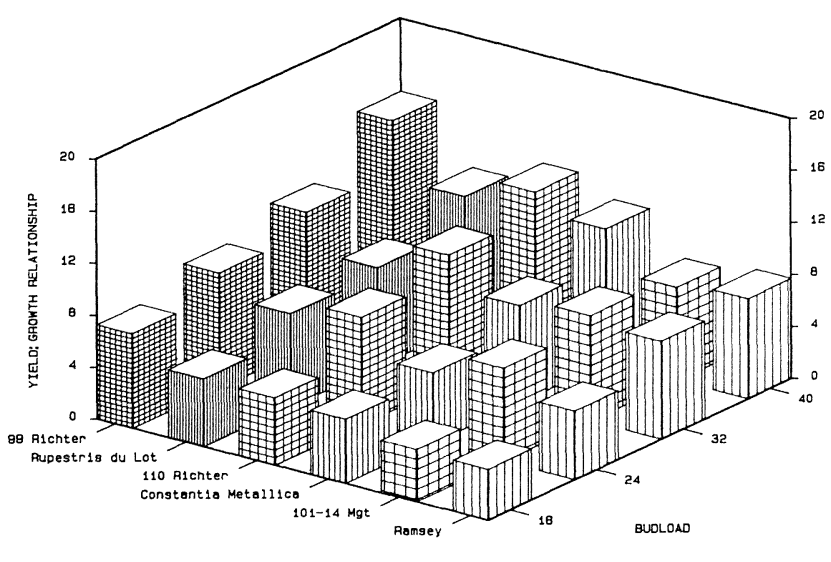

FIG. 1

The effect of budload and rootstock cultivar on the yield; growth relationship of Vitis vinifera cv. Muscat noir.

\section{Cluster characteristics:}

Bud load as well as rootstock cultivar had marked effects on cluster mass (Table 2). The smallest clusters were obtained with Rupestris du Lot pruned to 40 buds per vine, while Ramsey induced the largest clusters when pruned to 32 buds per vine. The latter is one of the reasons why no significant difference in the crop mass between the 32 and 40 bud load plots on Ramsey could be obtained (Table 1). Generally, Rupestris du Lot induced the lowest and 101-14 Mgt the highest cluster mass, while high bud loads reduced cluster mass for all rootstocks.

TABLE 1.

Effect of bud load and rootstock cultivar on the crop and cane mass (t. ha ${ }^{-1}$ ) of Vitis vinifera cv. Muscat noir. Robertson, $1979-1985$.

\begin{tabular}{|c|c|c|c|c|c|c|c|c|c|c|c|c|c|c|}
\hline \multirow{2}{*}{$\begin{array}{c}\text { Rootstock } \\
\begin{array}{c}\text { Bud load } \\
\text { per vine }\end{array}\end{array}$} & \multicolumn{2}{|c|}{$101-14 \mathrm{Mgt}$} & \multicolumn{2}{|c|}{99 Richter } & \multicolumn{2}{|c|}{110 Richter } & \multicolumn{2}{|c|}{ Ramsey } & \multicolumn{2}{|c|}{ C. Metallica } & \multicolumn{2}{|c|}{ Rup. du Lot } & \multicolumn{2}{|c|}{ Mean } \\
\hline & $\begin{array}{l}\text { Crop } \\
\text { mass }\end{array}$ & $\begin{array}{l}\text { Cane } \\
\text { mass }\end{array}$ & $\begin{array}{l}\text { Crop } \\
\text { mass }\end{array}$ & $\begin{array}{l}\text { Cane } \\
\text { mass }\end{array}$ & $\begin{array}{l}\text { Crop } \\
\text { mass }\end{array}$ & $\begin{array}{l}\text { Cane } \\
\text { mass }\end{array}$ & $\begin{array}{l}\text { Crop } \\
\text { mass }\end{array}$ & $\begin{array}{l}\text { Cane } \\
\text { mass }\end{array}$ & $\begin{array}{l}\text { Crop } \\
\text { mass }\end{array}$ & $\begin{array}{l}\text { Cane } \\
\text { mass }\end{array}$ & $\begin{array}{l}\text { Crop } \\
\text { mass }\end{array}$ & $\begin{array}{l}\text { Cane } \\
\text { mass }\end{array}$ & $\begin{array}{l}\text { Crop } \\
\text { mass }\end{array}$ & $\begin{array}{l}\text { Cane } \\
\text { mass }\end{array}$ \\
\hline $\begin{array}{l}16 \\
24 \\
32 \\
40\end{array}$ & $\begin{array}{l}19,32 \\
22,04 \\
25,88 \\
29,14\end{array}$ & $\begin{array}{l}4,77 \\
3,07 \\
3,18 \\
3,56\end{array}$ & $\begin{array}{l}16,11 \\
19,93 \\
17,86 \\
24,37\end{array}$ & $\begin{array}{l}2,21 \\
2,25 \\
1,71 \\
1,69\end{array}$ & $\begin{array}{l}22,98 \\
26,22 \\
28,79 \\
34,12\end{array}$ & $\begin{array}{l}4,42 \\
3,16 \\
2,89 \\
2,91\end{array}$ & $\begin{array}{l}19,64 \\
24,08 \\
31,85 \\
30,64\end{array}$ & $\begin{array}{l}5,05 \\
4,55 \\
4,22 \\
3,99\end{array}$ & $\begin{array}{l}17,49 \\
20,55 \\
24,75 \\
24,65\end{array}$ & $\begin{array}{l}3,53 \\
3,78 \\
3,30 \\
2,39\end{array}$ & $\begin{array}{l}12,97 \\
14,26 \\
16,84 \\
16,28\end{array}$ & $\begin{array}{l}2,47 \\
1,99 \\
2,21 \\
1,63\end{array}$ & $\begin{array}{l}18,09 \\
21,18 \\
24,33 \\
26,53\end{array}$ & $\begin{array}{l}3,74 \\
3,13 \\
2,92 \\
2,69\end{array}$ \\
\hline Mean & 24,10 & 3,65 & 19,57 & 1,97 & 28,03 & 3,35 & 26,55 & 4,45 & 21,86 & 3,25 & 15,09 & 2,08 & & \\
\hline$D$-value $(p \leqslant 0,05)$ & 1,614 & 0,923 & 1,637 & 0,495 & 1,598 & 0,672 & 2,014 & 0,509 & 2,743 & 0,834 & 1,976 & 0,596 & & \\
\hline
\end{tabular}

Crop mass

D-value $(p \leqslant 0,05):$ Rootstock $=2,195 ;$ Bud loads $=1,624$

Cane mass

D-value $(p \leqslant 0,05):$ Rootstock $=0,427 ;$ Bud loads $=0,314$ 
TABLE 2.

Effect of bud load and rootstock cultivar on the cluster and berry mass (g) of Vitis vinifera cv. Muscat noir. Robertson, 1979-1985.

\begin{tabular}{|c|c|c|c|c|c|c|c|c|c|c|c|c|c|c|}
\hline \multirow{2}{*}{$\begin{array}{c}\text { Rootstock } \\
\begin{array}{c}\text { Bud load } \\
\text { per vine }\end{array}\end{array}$} & \multicolumn{2}{|c|}{$101-14 \mathrm{Mgt}$} & \multicolumn{2}{|c|}{99 Richter } & \multicolumn{2}{|c|}{110 Richter } & \multicolumn{2}{|c|}{ Ramsey } & \multicolumn{2}{|c|}{ C. Metallica } & \multicolumn{2}{|c|}{ Rup. du Lot } & \multicolumn{2}{|c|}{ Mean } \\
\hline & $\begin{array}{c}\text { Cluster } \\
\text { mass }\end{array}$ & $\begin{array}{r}\text { Berry } \\
\text { mass }\end{array}$ & $\begin{array}{c}\text { Cluster } \\
\text { mass }\end{array}$ & $\begin{array}{c}\text { Berry } \\
\text { mass }\end{array}$ & $\begin{array}{c}\text { Cluster } \\
\text { mass }\end{array}$ & $\begin{array}{c}\text { Berry } \\
\text { mass }\end{array}$ & $\begin{array}{c}\text { Cluster } \\
\text { mass }\end{array}$ & $\begin{array}{r}\text { Berry } \\
\text { mass }\end{array}$ & $\begin{array}{c}\text { Cluster } \\
\text { mass }\end{array}$ & $\begin{array}{c}\text { Berry } \\
\text { mass }\end{array}$ & $\begin{array}{c}\text { Cluster } \\
\text { mass }\end{array}$ & $\begin{array}{r}\text { Berry } \\
\text { mass }\end{array}$ & $\begin{array}{c}\text { Cluster } \\
\text { mass }\end{array}$ & $\begin{array}{r}\text { Berry } \\
\text { mass }\end{array}$ \\
\hline 16 & 277,92 & 2,41 & 240,66 & 2,16 & 272,54 & 2,41 & 266,32 & 2,33 & 272,51 & 2,31 & 218,20 & 1,92 & 258,03 & 2,26 \\
\hline 24 & 276.81 & 2,42 & 211,02 & 2,04 & 252,57 & 2.31 & 268,59 & 2,44 & 250,54 & 2.14 & 214,21 & 1,90 & 245,62 & 2,21 \\
\hline 32 & 248.64 & 2.11 & 226,20 & 1,86 & 258,90 & 2.09 & 303,95 & 2.28 & 224.97 & 2,16 & 193,45 & 1,76 & 242,68 & 2,04 \\
\hline 40 & 265.42 & 2,05 & 215,51 & 1,84 & 259,02 & 2,03 & 256,08 & 2,26 & 214,27 & 2,11 & 187,44 & 1,86 & 232,96 & 2,02 \\
\hline Mean & 267.20 & 2.25 & 223,35 & 1,98 & 260,76 & 2,21 & 273,74 & 2,33 & 240,57 & 2,18 & 203,33 & 1,86 & & \\
\hline D-value $(p \leqslant 0,05)$ & ns & 0,31 & ns & 0,14 & ns & 0,181 & ns & ns & 34,778 & ns & 29,940 & ns & & \\
\hline
\end{tabular}

\section{Cluster mass}

D-value $(p \leqslant 0,05):$ Rootstocks $=23,857 ;$ Bud loads $=17,545$

\section{Berry mass}

D-value $(p \leqslant 0,05):$ Rootstocks $=0,129 ;$ Bud loads $=0,095$

ns $=$ not significant

The lowest berry mass was induced by Rupestris du Lot and 99 Richter. A general tendency for berry mass to decrease with increasing bud loads for all rootstocks was evident (Table 2). For 101-14 Mgt, 99 Richter and 110 Richter the decrease in berry mass obtained from low to high bud loads was significant. From the results it seems that differences in yield between different rootstocks could partly be explained by differences in berry mass.

\section{Budding percentage and bud fertility:}

Depending on the rootstock cultivar, the bud load had significant effects on the budding percentage (Table 3). All rootstocks obtained a $100 \%$ bud burst when pruned to 16 buds per vine and generally no significant decrease in budding percentage occurred with 24 and 32 buds per vine. Except in the case of Constantia Metallica, all rootstocks showed a significant decrease in bud burst with higher bud loads. The lowest overall budding percentage was obtained with Ramsey which coincides with results obtained for this vigorous rootstock in other experiments (data not shown). The two rootstocks, 101-14 Mgt and Ramsey, which yielded the highest cane mass with 40 buds per vine, induced longer shoots which had to be topped early in the growing season resulting in pronounced lateral shoot formation (data not shown).

Bud fertility was significantly affected by both bud load and rootstock cultivar (Table 3 ). Irrespective of bud load, 110 Richter and Ramsey induced significantly higher bud fertility than 101-14 Mgt, 99 Richter and Rupestris du Lot. The lowest bud fertility was obtained with Rupestris du Lot. For all rootstocks a significant decrease in bud fertility occurred with an increase in bud load from 16 to 40 buds per vine. A significant negative correlation $(\mathrm{r}=-0,892)$ was found between bud fertility and yield (data not shown) partly explaining why a $150 \%$ increase in bud load resulted in only a $47 \%$ increase in yield. It is postulated that the decrease in bud fertility was induced by unfavourable microclimatic conditions caused by a higher canopy density at higher bud loads.

\section{Leaf surface area and grape composition:}

It is clear that an increase in the bud load reduced the leaf surface area available to ripen the grapes (Table 4).

TABLE 3.

Effect of bud load and rootstock cultivar on the budding percentage (\%) and bud fertility (number of clusters per sprouted bud) of Vitis vinifera cv. Muscat noir. Robertson. 1979-1985.

\begin{tabular}{|c|c|c|c|c|c|c|c|c|c|c|c|c|c|c|}
\hline \multirow{2}{*}{$\begin{array}{c}\text { Rootstock } \\
\begin{array}{c}\text { Bud load } \\
\text { per vine }\end{array}\end{array}$} & \multicolumn{2}{|c|}{$101-14 \mathrm{Mgt}$} & \multicolumn{2}{|c|}{99 Richter } & \multicolumn{2}{|c|}{110 Richter } & \multicolumn{2}{|c|}{ Ramsey } & \multicolumn{2}{|c|}{ C. Metallica } & \multicolumn{2}{|c|}{ Rup. du Lot } & \multicolumn{2}{|c|}{ Mean } \\
\hline & $\begin{array}{l}\text { Budding } \\
\text { percen- } \\
\text { tage }\end{array}$ & $\begin{array}{l}\text { Bud } \\
\text { ferti- } \\
\text { lity }\end{array}$ & $\begin{array}{l}\text { Budding } \\
\text { percen- } \\
\text { tage }\end{array}$ & $\begin{array}{l}\text { Bud } \\
\text { ferti- } \\
\text { lity }\end{array}$ & $\begin{array}{l}\text { Budding } \\
\text { percen- } \\
\text { tage }\end{array}$ & $\begin{array}{l}\text { Bud } \\
\text { ferti- } \\
\text { lity }\end{array}$ & $\begin{array}{l}\text { Budding } \\
\text { percen- } \\
\text { tage }\end{array}$ & $\begin{array}{l}\text { Bud } \\
\text { ferti- } \\
\text { lity }\end{array}$ & $\begin{array}{l}\text { Budding } \\
\text { percen- } \\
\text { tage }\end{array}$ & $\begin{array}{l}\text { Bud } \\
\text { ferti- } \\
\text { lity }\end{array}$ & $\begin{array}{l}\text { Budding } \\
\text { percen- } \\
\text { tage }\end{array}$ & $\begin{array}{l}\text { Bud } \\
\text { ferti- } \\
\text { lity }\end{array}$ & $\begin{array}{l}\text { Budding } \\
\text { percen- } \\
\text { tage }\end{array}$ & $\begin{array}{l}\text { Bud } \\
\text { ferti- } \\
\text { lity }\end{array}$ \\
\hline $\begin{array}{l}16 \\
24 \\
32 \\
40\end{array}$ & $\begin{array}{r}100 \\
100 \\
100 \\
93\end{array}$ & $\begin{array}{l}1,60 \\
1,43 \\
1,34 \\
1,28\end{array}$ & $\begin{array}{r}100 \\
99 \\
98 \\
94\end{array}$ & $\begin{array}{l}1,64 \\
1,51 \\
1.14 \\
1.15\end{array}$ & $\begin{array}{r}100 \\
100 \\
97 \\
96\end{array}$ & $\begin{array}{l}1,81 \\
1,57 \\
1,40 \\
1,30\end{array}$ & $\begin{array}{r}100 \\
96 \\
98 \\
93\end{array}$ & $\begin{array}{l}1,77 \\
1,54 \\
1,59 \\
1,36\end{array}$ & $\begin{array}{r}100 \\
99 \\
98 \\
99\end{array}$ & $\begin{array}{l}1,71 \\
1,54 \\
1,36 \\
1,20\end{array}$ & $\begin{array}{r}100 \\
99 \\
96 \\
95\end{array}$ & $\begin{array}{l}1,48 \\
1,29 \\
1,18 \\
0,97\end{array}$ & $\begin{array}{r}100 \\
99 \\
98 \\
95\end{array}$ & $\begin{array}{l}1,67 \\
1,48 \\
1,33 \\
1,21\end{array}$ \\
\hline Mean & 98 & 1,41 & 98 & 1.36 & 98 & 1.52 & 96 & 1,56 & 99 & 1,45 & 97 & 1,23 & & \\
\hline $\begin{array}{l}\text { D-value } \\
(p \leqslant 0,05)\end{array}$ & 5,2 & 0,201 & 4,7 & 0,251 & 3,9 & 0,152 & 3,9 & 0,224 & ns & 0,203 & 4,5 & 0,172 & & \\
\hline
\end{tabular}

\section{Budding percentage}

D-value $(p \leqslant 0,05):$ Rootstocks $=2,8 ;$ Bud loads $=2,1$

Bud fertility

D-value $(p \leqslant 0,05):$ Rootstocks $=0,115 ;$ Bud loads $=0,085$

$\mathrm{ns}=$ not significant 
TABLE 4.

Effect of bud load and rootstock cultivar on the leaf surface area $\left(\mathrm{cm}^{2}\right)$ per unit mass of grapes $(\mathrm{g})$ of Vitis vinifera cv. Muscat noir. Robertson, 1980-1985.

\begin{tabular}{|c|c|c|c|c|c|c|c|}
\hline Rootstock & $101-14 \mathrm{Mgt}$ & 99 Richter & 110 Richter & Ramsey & C. Metallica & Rup. du Lot & Mean \\
\hline \multicolumn{8}{|l|}{ Bud load per vine } \\
\hline $\begin{array}{l}16 \\
24 \\
32 \\
40\end{array}$ & $\begin{array}{l}14,80 \\
14,23 \\
13,20 \\
11,30\end{array}$ & $\begin{array}{r}10,88 \\
10,82 \\
9,65 \\
8,25\end{array}$ & $\begin{array}{r}12,08 \\
11,44 \\
10,50 \\
9,14\end{array}$ & $\begin{array}{l}15,11 \\
14,50 \\
10,65 \\
10,26\end{array}$ & $\begin{array}{l}15,15 \\
13,04 \\
12,01 \\
11,68\end{array}$ & $\begin{array}{r}12.26 \\
11,03 \\
9.21 \\
8.45\end{array}$ & $\begin{array}{r}13,38 \\
12,51 \\
10.87 \\
9,85\end{array}$ \\
\hline Mean & 13,38 & 9,90 & 10,79 & 12,63 & 12,97 & 10.24 & \\
\hline D-value $(p \leqslant 0,05)$ & ns & ns & ns & ns & ns & ns & \\
\hline
\end{tabular}

D-value $(\mathrm{p} \leqslant 0,05)$ : Rootstocks $=3,043 ;$ Bud loads $=2,238$

$\mathrm{ns}=$ not significant

This partly explains the decrease in sugar and acid concentration which occurred with an increase in bud load (Table 5). It is widely accepted that a leaf surface area of $10-12 \mathrm{~cm}^{2}$ is necessary to ripen $1 \mathrm{~g}$ of grapes optimally and the same was found in this study. High bud loads had an adverse effect on this parameter especially in the case of certain rootstocks and this corresponds well with the skin colour density (Hunter \& De la Harpe, 1987). On average 99 Richter had a significantly negative effect on this parameter compared to 101-14 Mgt and Constantia Metallica.

The lowest bud load induced a significantly higher acid concentration than the two highest bud loads while 99 Richter and Rupestris du Lot produced significantly less acid than the other rootstocks (Table 5). As in the case of sugar concentration (Table 5), a general decline in acid concentration was found with increased bud loads while the $\mathrm{pH}$ of the must (Table 5) was not affected. Rootstock cultivar, however, affected the $\mathrm{pH}$ with Ramsey and Rupestris du Lot inducing the highest and 99 Richter the lowest $\mathrm{pH}$ in the must.

\section{Wine quality:}

Sweet fortified wines were made from some experimental plots during the period 1980-1986. Although no differences in wine quality occurred between rootstocks, quality decreased with an increase in bud load (data not shown). The decrease in quality was mainly ascribed to a decrease in the colour expression of the wine and corresponds with the results obtained by Hunter \& De la Harpe (1987).

\section{CONCLUSIONS AND RECOMMENDATIONS}

Bud load as well as rootstock cultivar significantly affects yield and shoot growth. Generally, an increase in bud load increases yield and decreases vegetative growth. Yield increase is not proportional to increases in bud load int. al. because of a decrease in/bud fertility. It is clear that different rootstock cultivars require different bud loads. Under the conditions of this experiment, 110 Richter, Ramsey and 101-14 Mgt gave the best results concerning growth and production while symptoms of overcropping became evident with other rootstocks, especially when a budload of 40 buds per vine was used. In combination with Red Muscadel, Rupestris du Lot and 99 Richter perform poorly as far as leaf surface area per unit mass of grapes and grape composition are concerned.

Generally, increases in bud load negatively affect cluster mass, budding percentage and bud fertility. These factors also sufficiently explain the production and shoot growth effects caused by different bud loads on different rootstocks. Evidently, the weaker the inhe-

TABLE 5.

Effect of bud load and rootstock cultivar on the sugar concentration $\left({ }^{\circ} \mathrm{B}\right)$, acid concentration $\left(\mathrm{g} . l^{-1}\right)$ and $\mathrm{pH}$ of Vitis vinifera cv. Muscat noir. Robertson. $1979-1985$.

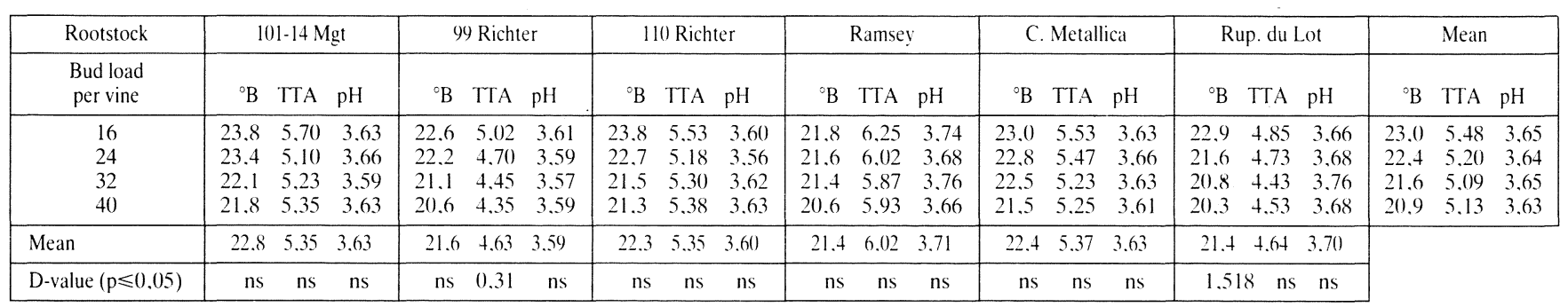

Sugar concentration

D-value $(p \leqslant 0,05):$ Rootstocks $=1,08 ;$ Bud loads $=0,794$

Acid concentration

D-value $(p \leqslant 0,05):$ Rootstocks $=0,420 ;$ Bud loads $=0,309$

pH

D-value $(p \leqslant 0,05):$ Rootstocks $=0,061 ;$ Bud loads $=n s$

$\mathrm{ns}=$ not significant 
rent vigour of a rootstock, the more pronounced the detrimental effect of increased bud loads become, mainly because of the negative effect of high bud loads on the leaf surface area per unit mass of grapes index. It is evident that the turning point in quality is at different bud loads for different rootstocks and under the conditions of this trial 110 Richter and Ramsey performed better than the other rootstocks.

\section{LITERATURE CITED}

ANTCLIFF, A.J., 1965. A comparison of cropping levels in the Sultana. Vitis 5, 1-9.

ARCHER, E., 1983. Evaluasie van verskillende snoeimetodes vir Cabernet Sauvignon. Die Wynboer 621, 65-69.

ARCHER, E., 1984. Invloed van ooglading op die prestasie van wyndruifstokke. Wynboer Tegnies 8, 11-15.

ARCHER, E., 1985. Wintersnoei van wingerd. Wynboer Tegnies 11, 4-7.

BALASUBRAHMANYAM, V.R., EIFERT, J. \& DIOFASI, L., 1978. Nutrient reserves in grapevine canes as influenced by cropping levels. Vitis 17, 23-29.

BALASUBRAHMANYAM, V.R., EIFERT, J. \& DIOFASI, L., 1979. Vine behaviour and wine composition in Italian Riesling grapes as influenced by differential cropping levels. Vitis 18, 122126.

BRAVDO, B., HEPNER, Y., LOINGER, C., COHEN, S. \& TABACMAN, H., 1984. Effect of crop level on growth, yield and wine quality of a high yielding Carignane vineyard. Am. J. Enol. Vitic. 35, 247-253.

BRAVDO, B., HEPNER, Y., LOINGER, C., COHEN, S. \& TABACMAN, H., 1985a. Effect of crop level and crop load on growth, yield, must and wine composition, and quality of Cabernet Sauvignon. Am. J. Enol. Vitic. 36, 125-131.

BRAVDO, B., HEPNER, Y., LOINGER, C., COHEN, S. \& TABACMAN, H., 1985b. Effect of irrigation and crop level on growth, yield and wine quality of Cabernet Sauvignon. Am. J. Enol. Vitic. 36, 132-139.

CAWTHON, D.L. \& MORRIS, J.R., 1977. Yield and quality of Concord grapes as affected by pruning severity, nodes per bearing unit, training system, shoot positioning and sampling date in Arkansas. J. Am. Soc. Hort. Sci. 102, 760-767.

CHRISTENSEN, L.P., 1981. Lighter pruning lessens bunch rot of Chenin blanc grapes. California Agriculture 10-11.

DIXON, W.J., BROWN, M.B., ENGELMAN, L., FRANE, J.W., HILL, M.A., JENNRICH, R.I. \& TOPOLAREK, J.D., 1983. BMDP Statistical software. Univ. Calif. Press. London.

FREEMAN, B.M., LEE, T.H. \& TURKINGTON, C.R., 1979. Interaction of irrigation and pruning level on growth and yield of Shiraz vines. Am. J. Enol. Vitic. 30, 218-223.

FREEMAN, B.M., LEE, T.H. \& TURKINGTON, C.R., 1980. Interaction of irrigation and pruning level on grape and wine quality of Shiraz vires. Am. J. Enol. Vitic. 31, 124-135.

HEPNER, Y. \& BRAVDO, B., 1985. Effect of crop level and drip irrigation scheduling on the potassium status of Cabernet Sauvig- non and Carignane vines and its influence on must and wine composition and quality. Am. J. Enol. Vitic. 36, 140-147.

HEPNER, Y., BRAVDO, B., LOINGER, C., COHEN, S. \& TABACMAN, H., 1985. Effect of drip irrigation schedules on growth, yield, must composition and wine quality of Cabernet Sauvignon. Am. J. Enol. Vitic. 36, 77-85.

HUNTER, J.J. \& DE LA HARPE, A.C., 1987. The effect of rootstock cultivar and bud load on the colour of Vitis vinifera L. cv. Muscat rouge (Red Muscadel) grapes. S. Afr. J. Enol. Vitic. 8, $1-5$.

JOOSTE, L.J., 1983. Invloed van opleistelsel en ooglading op vegetatiewe groei en produksie van Chenin blanc in Robertson. Die Wynboer 624, 69-73.

KLIEWER, W.M., FREEMAN, B.M. \& HOSSOM, C., 1983. Effect of irrigation, crop level and potassium fertilization on Carignane vines. I Degree of water stress and effect on growth and yield. Am. J. Enol. Vitic. 34, 186-197.

LIDER, L.A., KASIMATIS, A.N. \& KLIEWER, W.M., 1973. Effect of pruning severity and rootstock on growth and yield on two grafted, cane-pruned wine grape cultivars. J. Am. Soc. Hort. Sci. 91, 8-11.

LIDER, L.A., KASIMATIS, A.N. \& KLIEWER, W.M., 1975. Effect of pruning severity on the growth and fruit production of Thompson Seedless grapevines. Am. J. Enol. Vitic. 26, 175-178.

MORRIS, J.R. \& CAWTHON, D.L., 1980. Yield and quality response of Concord grapes to training systems and pruning severity in Arkansas. J. Am. Soc. Hort. Sci. 105, 307-310.

WEAVER, R.J., AMERINE, M.A. \& WINKLER, A.J., 1957. Preliminary report of effect of level of crop on development of colour in certain red wine grapes. Am. J. Enol. Vitic. 8, 157-166.

WEAVER, R.J., McCUNE, S.B. \& AMERINE, M.A., 1962. Effect of level of crop on vine behaviour and wine composition in Carignan and Grenache grapes. Am. J. Enol. Vitic. 12, 175-184.

WEAVER, R.J. \& POOL, R.M., 1968. Effect of various levels of cropping on Vitis vinifera grapevines. Am. J. Enol. Vitic. 19, 185193.

WINKLER, A.J., 1964. Effects of overcropping. Am. J. Enol. Vitic. 5, 4-12.

ZEEMAN, A.S., 1981. Oplei. In: Wingerdbou in Suid-Afrika, 185201. J. Burger \& J. Deist (Eds.). V.O.R.I., Private Bag X5026, 7600 Stellenbosch, R.S.A.

ZEEMAN, A.S., \& ARCHER, E., 1981. Stokontwikkeling, wintersnoei en somerbehandeling. In: Wingerdbou in Suid-Afrika, 202233. J. Burger \& J. Deist (Eds.). V.O.R.I., Private Bag X5026, 7600 Stellenbosch, R.S.A. 